\title{
Faktor-Faktor Yang Mempengaruhi Kepuasan Konsumen Pengguna Layanan Pembelian Secara Daring: Peran Kepuasan Konsumen Sebagai Mediator
}

\author{
Nova Ch. Mamuaya ${ }^{1}$, Aditya Pandowo ${ }^{2}$ \\ 1, 2 Universitas Negeri Manado \\ 1novachmamuaya@unima.ac.id, 2aditya.pandowo@unima.ac.id
}

\begin{abstract}
The purpose of this study is to analyze the influence of several antecedents of customer satisfaction in the online shopping industry, namely site design, time savings, product variation, and shipping performance, and its consequence on customer satisfaction and word of mouth. This study uses purposive sampling with repeat buyer criteria. 100 samples qualify and deserve to be tested after testing their validity and reliability. The results showed that site design, time savings, and delivery performance significantly affected customer satisfaction. Meanwhile, site design, time savings, and product variations affect word of mouth. In addition, the results also confirm the hidden role of customer satisfaction as a partial mediating variable. Thus, the market must increase the availability of products and services to increase customer satisfaction in order to increase word of mouth activities.
\end{abstract}

Keywords: electronic commerce; word of mouth; satisfaction; site design; time savings; product variations; delivery performance

\begin{abstract}
Abstrak
Tujuan dari penelitian ini adalah untuk menganalisis pengaruh beberapa anteseden dari kepuasan pelanggan dalam industri belanja daring, yaitu desain situs, penghematan waktu, variasi produk, dan kinerja pengiriman, dan konsekuensinya pada kepuasan pelanggan dan word of mouth. Penelitian ini menggunakan purposive sampling dengan kriteria pembeli berulang. 100 sampel memenuhi syarat dan layak untuk diuji setelah pengujian validitas dan reliabilitas. Hasil penelitian menunjukkan bahwa desain situs, penghematan waktu, dan kinerja pengiriman secara signifikan mempengaruhi kepuasan pelanggan. Sementara itu, desain situs, penghematan waktu, dan variasi produk berpengaruh pada word of mouth. Selain itu, hasilnya juga mengkonfirmasi peran tersembunyi dari kepuasan pelanggan sebagai variabel mediasi secara parsial. Dengan demikian, pasar harus meningkatkan ketersediaan produk dan layanan untuk meningkatkan kepuasan pelanggan dalam rangka meningkatkan aktivitas word of mouth.

Kata kunci: perdagangan elektronik; word of mouth; kepuasan; desain situs; penghematan waktu; variasi produk; kinerja pengiriman
\end{abstract}




\section{PENDAHULUAN}

Evolusi teknologi dalam membantu umat manusia untuk mencapai kebutuhan dan kemauan mereka bergerak dengan cara yang cepat dan mudah. Munculnya internet memungkinkan orang tidak hanya untuk berkomunikasi dalam area yang luas, tetapi juga untuk mencari informasi, memperkenalkan produk dan layanan mereka, dan menjalankan transaksi bisnis. Kemajuan internet juga mengubah cara bisnis dijalankan (Kaur, 2011) atau paradigma bisnis secara keseluruhan. Sifat internet yang tanpa batas sangat menguntungkan bagi penjual dan pembeli dalam menyiasati isu toko secara fisik, interaksi, dan transaksi.

E-commerce adalah bentuk aplikasi ekonomi internet dalam bisnis elektronik (Fichter, 2003) dengan berbagi informasi bisnis, menjaga hubungan bisnis, dan melakukan transaksi bisnis melalui jaringan telekomunikasi (Zwass, 1996). Dengan kata lain, e-commerce adalah aplikasi bisnis berbasis virtual di mana pihak-pihak yang terlibat dalam aktivitas sebagian besar berinteraksi melalui elektronik daripada kontak fisik dalam nilai tukar. Dalam beberapa masa terakhir, e-commerce telah mempengaruhi kegiatan bisnis seperti ritel, perbankan, rumah sakit, transportasi, dan lain-lain. Pemberdayaan situs dan aplikasi online adalah kunci utama untuk daya tarik e-commerce. Meskipun dapat memanfaatkan media lain seperti email atau media sosial, tetapi popularitas mereka sangat signifikan.

Dalam konteks literatur pemasaran, e-commerce merujuk pada upaya memasarkan produk atau layanan, dan untuk membangun hubungan pelanggan antara penjual dan pembeli dengan menggunakan media elektronik atau internet (Kotler \& Armstrong, 2014). Tidak dapat dipungkiri bahwa e-commerce telah menjadi protagonis di dunia bisnis belakangan ini. Karena persaingan di antara perusahaan-perusahaan di industri menjadi ketat dan pesaing baru muncul, semua pelaku pasar yang ada perlu mempertahankan pelanggan dengan meningkatkan kepuasan mereka. Sebagai kunci utama untuk keberlanjutan merek dan perusahaan, kepuasan pelanggan telah menjadi masalah utama dalam mempertahankan hubungan pelanggan.

Oleh karena itu, perusahaan perlu menyediakan beberapa elemen untuk mendukung upaya mereka dalam mempengaruhi kepuasan pelanggan, yaitu: (1) desain situs web, yaitu tampilan visual yang bertindak sebagai pemisah antara pembeli-penjual (Luo, Ba, \& Zhang, 2012). Mereka berpendapat bahwa desain yang baik memiliki peluang lebih besar dalam membuat kepuasan pelanggan. (2) Penghematan waktu, merupakan perbandingan antara waktu yang tersedia dan jumlah tugas dan durasi waktu yang harus dilakukan (Richbell, 2007). (3) Variasi produk, merupakan sejumlah atau koleksi produk yang dibedakan oleh hal-hal tertentu untuk memenuhi persyaratan diversifikasi pelanggan (Elmaraghy, Elmaraghy, Scuch, \& Piller, 2013), dan (4) Kinerja pengiriman, merupakan kemampuan perusahaan untuk mendistribusikan produk dan layanan dengan aman dan sesuai jadwal.

Meskipun study dalam industry digital telah banyak dilakukan pada decade terakhir ini, kemajuan teknologi dan evolusi media electronic marketplace mengharuskan kita untuk tetap menyajikan data dan informasi terkini. Dalam penelitian ini, perspektif pembeli dari konsumen usia muda menjadi titik perhatian. Hal ini dipandang sesuai dengan tipikal alamiah mereka sebagai konsumen yang emosional, hedonis, tanggap dalam kemajuan teknologi, dan memiliki keinginan besar untuk diakui oleh komunitas. Konsumen dengan rentang usia ini lebih bervariasi dalam pemilihan produk pembelian. Oleh karena itu, penelitian ini 
tidak membatasi kategori produk sebagai batasan penelitian mengingat sejumlah electronic marketplace di Indonesia tidak mengkhususkan penjualan pada satu industry saja.

Studi ini dilakukan untuk menganalisis apakah faktor-faktor yang diuraikan di atas benar-benar dapat mempengaruhi kepuasan pelanggan di industri e-commerce Indonesia. Untuk menjawab hubungan antar konstruk dalam penelitian ini dengan word of mouth sebagai bagian dari novelty penelitian ini disusun dengan kerangka teori anteseden dari karakterisitk pasar daring dan impak yang dihasilkan. Kemudian, penjabaran metodologi dan instrumen yang digunakan dalam penelitian ini. Selanjutnya, penyajian analisis statistik dan intepretasi hasil penelitian. Terakhir, simpulan dan keterbatasan penelitian dan saran bagi penelitian dimasa depan.

Menurut Kotler \& Keller, (2016) pemasaran mengacu pada proses menciptakan, berkomunikasi, memberikan nilai kepada pelanggan dan membangun hubungan pelanggan untuk mendapatkan manfaatnya seperti profitabilitas dan ekuitas pelanggan dalam periode jangka panjang. Mereka juga menyatakan bahwa pemasaran adalah proses mengidentifikasi kebutuhan manusia dan sosial, kemudian mencocokkan produk perusahaan dengan kebutuhan mereka, dan mendapatkan keuntungan darinya. Dalam beberapa hari terakhir, kampanye pemasaran dapat lebih mudah dilakukan melalui internet. Pemasaran internet (e-marketing atau virtual marketing) adalah upaya memasarkan suatu produk atau layanan dan juga membangun hubungan melalui atau menggunakan media elektronik atau internet (Kotler \& Armstrong, 2014). Perusahaan online terutama menggunakan strategi untuk memasarkan produk atau layanan mereka secara online, seperti strategi desain situs, promosi online, pemasaran email, optimisasi mesin pencari, media sosial, iklan bayar per klik, blog, dan lain-lain.

Tujuan dari pendekatan e-marketing adalah untuk menjangkau pelanggan potensial melalui saluran di mana orang menghabiskan waktu untuk mencari, berbelanja, atau bahkan bersosialisasi secara online. Keuntungan dari e-marketing adalah memperluas jangkauan pasar di wilayah tertentu atau di luar negeri. Dalam hal pengeluaran, e-marketing lebih murah daripada yang konvensional. Perdagangan elektronik atau e-commerce didefinisikan sebagai penggunaan Internet dan intranet untuk membeli, menjual, mengangkut, atau memperdagangkan data, barang, atau layanan (Turban, et al, 2015). Inti dari e-commerce adalah berbagi informasi bisnis, menjaga hubungan bisnis dan melakukan transaksi bisnis melalui jaringan telekomunikasi (Zwass, 1996). Tujuan dari e-commerce adalah untuk menciptakan, mengubah, dan mendefinisikan kembali hubungan untuk penciptaan nilai antara organisasi dan individu.

Namun, e-commerce sering salah paham untuk e-business. E-business lebih luas dari e-commerce karena tidak hanya berbicara tentang perdagangan tetapi juga kolaborasi mitra bisnis, layanan pelanggan, lowongan pekerjaan, dan lain-lain (Strauss \& Frost, 2014), tapi juga memberikan e-learning, dan melakukan transaksi elektronik dalam suatu organisasi (Turban et al., 2015). Menurut mereka, platform e-commerce biasanya didasarkan pada pasar elektronik, yang merupakan lokasi digital di mana pembeli dan penjual melakukan transaksi komersial melalui internet dan intranet dalam organisasi

Kepuasan mengacu pada respons emosional pelanggan tentang seluruh pengalaman mereka di titik pasca pembelian (Ekinci, Dawes, \& Massey, 2008). Sementara itu definisi 
lain diungkapkan oleh Kotler \& Keller, (2016) yang menyatakan bahwa kepuasan adalah keadaan emosional berupa kesenangan atau kekecewaan yang dirasakan seseorang dengan membandingkan persepsi mereka (hasil) dan ekspektasi dari kinerja suatu produk atau layanan. Sementara itu, kepuasan dalam hal penggunaan teknologi berarti pemenuhan yang menyenangkan berdasarkan hubungan pemasaran yang dimediasi oleh teknologi (Szymanski \& Hise, 2000). Berdasarkan definisi tersebut, kepuasan adalah perbandingan antara harapan pelanggan dan kinerja produk atau layanan. Perbandingan merujuk bahwa pelanggan akan merasa puas jika kinerja produk atau layanan memenuhi harapan mereka. Pelanggan akan senang jika kinerja produk atau layanan melebihi harapan standar mereka. Sebaliknya, mereka akan kecewa jika kinerja produk atau layanan di bawah harapan standar mereka.

Beberapa investigasi menyatakan bahwa kepuasan pelanggan dapat dicapai dengan meningkatkan kualitas produk atau layanan yang sangat baik (Suchánek \& Králová, 2014), pengalaman positif masa lalu dan kongruensi diri (Morgan-Thomas \& Veloutsou, 2013; Tsai, Chang, \& Ho, 2015); bagaimana mereka mempersepsikan kualitasnya (Delgado-Ballester \& Munuera-Alemán, 2001), maupun keakraban dan kredibilitas merek (Ha \& Perks, 2005).

Sementara itu, pelanggan yang puas dengan kinerja produk atau layanan akan mengarah ke loyalitas (Brakus, Schmitt, \& Zarantonello, 2009), meningkatkan reputasinya (Delgado-Ballester \& Munuera-Alemán, 2001), meningkatkan kemungkinan niat untuk membeli kembali (Curry \& Gao, 2012), membangun kepercayaan satu sama lain (Ha \& Perks, 2005), meningkatkan kesediaan pelanggan untuk berbagi dari mulut ke mulut (Babin, Lee, Kim, \& Griffin, 2005), membangun kualitas hubungan (Morgan-Thomas \& Veloutsou, 2013), dan memperkuat memori merek dan meningkatkan ke preferensi (Tsai et al., 2015). Selain itu, beberapa penelitian membuktikan bahwa kepuasan pelanggan dapat berperan sebagai variabel intervening dari kualitas situs web untuk niat pembelian kembali (Tandon, Kiran, \& Sah, 2017) dan memberikan efek moderasi dari pengalihan biaya ke niat pembelian kembali (Ting, 2014).

Desain situs didefinisikan sebagai desain tampilan pengguna yang ditawarkan kepada pelanggan (J. Kim \& Lee, 2002). Desain situs merujuk pada elemen estetika yang merupakan daya tarik visual, seperti warna, grafik, atau teks, yang diorganisasikan dengan mudah digunakan dan langsung disajikan kepada pengunjung situs web (Bressolles \& Durrieu, 2011). Dalam ekonomi digital, situs web berfungsi sebagai pasar antara pengecer dan konsumen. Oleh karena itu, penyedia perlu mengembangkan navigasi yang mudah digunakan dan desain yang menarik. Tujuannya bukan hanya untuk mempertahankan pelanggan lebih lama tetapi juga mempertahankan mereka untuk mengunjungi kembali. Pernyataan ini didukung oleh Shergill \& Chen, (2005) yang mengidentifikasi karakteristik situs web sebagai faktor utama persepsi konsumen dalam pembelian online.

Desain situs web yang elegan harus terdiri dari tata letak yang jelas, navigasi yang mudah, penampilan yang tertata dengan baik, dan tampilan informasi terkini (Tao, Lu, \& Wang, 2009) dan kecepatan pengunduhan yang ditawarkan (Francis, 2009).

Penghematan waktu mencerminkan perbandingan tekanan waktu yang dirasakan yang dihadapi oleh individu untuk memutuskan kegiatan. Penghematan waktu didefinisikan sebagai sejauh mana individu mengalami kekurangan waktu dalam menjalankan tugas hidup sehari-hari (Settle dan Alreck (1991). 
Tekanan waktu yang dirasakan dapat muncul dari dua sumber berbeda, situasional dan pribadi. Sumber situasional sangat umum dan mudah dikenali. Bisa jadi karena banyak pekerjaan yang harus dilakukan sementara waktu tidak terbatas. Orang yang menghadapi masalah ini akan menyadari bahwa belanja online adalah solusi terbaik. Tidak hanya menghemat waktu mereka yang berharga, tetapi juga menghemat energi mereka. Mereka tidak harus mengunjungi toko secara fisik, menghilangkan antrian atau terjebak dalam kerumunan, dan tidak takut masalah jam kantor. Secara keseluruhan, pelanggan mencari beberapa indikator, seperti: kemudahan penggunaan, transaksi cepat, kenyamanan dalam hal waktu dan usaha (Seiders, Voss, \& Godfrey, 2007).

Singkatnya, efisiensi waktu menjadi alasan utama untuk belanja online (Devaraj, Fan, \& Kohli, 2002) melalui penelusuran yang lebih cepat dan mekanisme mesin pencari. Oleh karena itu, penghematan waktu dan biaya adalah isyarat untuk evaluasi.

Variasi produk didefinisikan sebagai bermacam-macam produk yang tersedia di dalam toko, dan disediakan oleh perusahaan atau organisasi (Kotler \& Keller, 2016). Produk varian mencerminkan sejauh mana ketersediaan keanekaragaman produk yang ditawarkan oleh penyedia dalam satu-satunya produk. Perbedaan dari permintaan pelanggan dalam hal kebutuhan, keinginan, selera, atau anggaran mereka adalah alasan di balik keputusan dari pengecer online dalam menawarkan berbagai variasi produk.

Ada dua dimensi yang terlibat dalam menentukan variasi produk, luasnya produk yang ditawarkan oleh perusahaan, dan kemungkinan produk baru dapat menggantikan yang sudah ada (Fisher, Ramdas, \& Ulrich, 2014). Variasi produk dapat diklasifikasikan kedalam dua jenis, yaitu variasi spasial dan variasi generik (Martin \& Ishii, 2000). Variasi spasial mengacu pada variasi produk saat ini yang ditawarkan oleh perusahaan sedangkan varietas generasional berarti model produk di seluruh generasinya.

Evolusi variasi produk telah muncul untuk memenuhi preferensi konsumen tentang suatu produk. Jika perusahaan mampu menyediakan apa yang dibutuhkan pelanggan, itu tidak hanya memuaskan pelanggan, tetapi juga meningkatkan penjualan, pangsa pasar, dan keuntungan mereka. Selanjutnya, perusahaan dapat menarik dan menangkap pelanggan potensial baru, dan mempertahankan pelanggan yang tersisa dalam bentuk hubungan merek-pelanggan.

Dalam konteks e-commerce, variasi produk tidak akan mengganggu ruang penyimpanan karena mereka tidak memiliki batasan dalam masalah itu. Dengan demikian, hal tersebut bisa menjadi titik keuntungan bagi pasar online untuk menawarkan lebih banyak produk daripada toko konvensional.

Kinerja pengiriman merupakann isu yang tidak dapat disangkal karena pelanggan harus berurusan dengan berbagai kendala, seperti: cuaca buruk (musim tertentu), akses, keterlambatan, kerusakan produk, atau kesalahan pengiriman baik produk itu sendiri atau tujuan. Oleh karena itu, kinerja pengiriman telah menjadi masalah penting karena pembelian online rentan dengan risiko dan ketidakpastian. Munculnya situasi ini muncul dikarenakan pembeli harus membayar terlebih dahulu tanpa jaminan kapan mereka akan mendapatkan produk.

Kinerja pengiriman menjelaskan tentang seberapa baik produk diperlakukan dan dikirim 
ke tujuan dengan kecepatan dan akurasi yang tepat (Kotler \& Keller, 2016). Dengan kata lain, kinerja pengiriman tidak hanya tentang apakah produk akan tiba, tetapi juga tentang lamanya waktu, pengemasan (terutama untuk produk yang rentan), dan tujuan yang tepat.

Untuk menghilangkan masalah-masalah tersebut, perusahaan perlu menawarkan pemecahan masalah seperti: (1) perusahaan perlu menjamin produk tiba dengan selamat dalam keadaan apa pun. Jika cuaca buruk terlibat dalam aktivitas pengiriman, maka perlu adanya asuransi sebagai jaminan, (2) perusahaan harus bertanggung jawab jika produk rusak atau rusak dalam pengiriman dengan menawarkan program pengembalian atau penggantian dengan produk baru atau voucher pembelian kembali, (3) perusahaan perlu untuk menjamin bahwa pelanggan akan mendapatkan produk yang sama dengan pesanan mereka di situs belanja.

Masalah itu akan menjadi tantangan bagi perusahaan untuk memperbaiki masalah sebelum pelanggan berubah pikiran untuk pergi ke toko secara langsung. Jika perusahaan dapat menyelesaikan masalah tersebut, maka kepuasan akan muncul. Akibatnya, pelanggan akan mengunjungi kembali dan membeli kembali di web.

Word of mouth didefinisikan sebagai proses transfer komunikasi informal dari seseorang ke seseorang mengenai pertukaran komentar, pemikiran, dan ide. Word of mouth telah menjadi kampanye pemasaran yang sangat efisien karena perusahaan tidak perlu memiliki pengeluaran apa pun dan ini merupakan agen pemasaran yang baik untuk menarik konsumen. Keuntungan dari Word of mouth adalah dapat terjadi baik dalam pasar digital maupun analog. Meskipun demikian, arti penting dari Word of mouth masih dapat diperdebatkan mengenai cara yang paling efisien dari Word of mouth daring atau konvensional. Word of mouth konvensional terdiri dari pertukaran testimonial secara langsung selama percakapan. Itulah sebabnya seorang komunikator dapat mempengaruhi orang tersebut secara efisien. Gagasan ini mendukung penelitian sebelumnya oleh (Keller \& Fay, 2009) yang berpendapat dengan cara yang sama. Namun, pendapat yang berlawanan memastikan bahwa kata Word of mouth elektronik lebih efisien karena kemampuannya untuk mempengaruhi lebih banyak orang dalam waktu singkat (Phelps, et al, 2004) karena adanya faktor kecepatan dan kenyamanan, tidak memerlukan interaksi tatap muka, dan individu dapat berbagi pemikiran dan pengalaman dengan kata-kata tertulis (Bickart \& Schindler, 2001).

Desain situs merupakan focus penting meningat perannya sebagai penghubung antarmuka antara konsumen dan pengecer. Desain situs perlu mempertimbangkan tampilan yang menarik, mudah, dan sederhana. Desain yang baik tidak hanya mengundang konsumen untuk menggulir tetapi juga mengurangi waktu pencarian dan meningkatkan kemungkinan untuk membeli. Akibatnya, mereka akan puas dan senang dengan desainnya (Luo et al., 2012). Berdasarkan investigasi sebelumnya, sebagian besar percaya bahwa desain situs web yang baik akan mempengaruhi kepuasan pelanggan (Guo, Ling, \& Liu, 2012; Lin, Wu, \& Chang, 2011) dalam konteks belanja online. Hipotesis pertama yang diajukan:

\section{H1: Desain situs web secara positif mempengaruhi kepuasan}

Ketika sebuah situs dirancang dalam tampilan visual yang lebih baik, mudah dalam navigasi, dan informatif, kemungkinan kepuasan pelanggan akan meningkat. Sebaliknya, situs 
web dengan tampilan yang menyilaukan, rumit, dan membingungkan akan meningkatkan peluang dari mulut ke mulut yang negatif. Oleh karena itu, perusahaan perlu menyediakan tampilan web yang baik agar konsumen dengan inisiatif sendiri memberikan informasi positif kepada rekannya mengenai situs tersebut. Berdasarkan pemikiran tersebut hipotesis kedua yang diajukan:

\section{H2: Desain situs mempengaruhi Word of mouth}

Penghematan waktu adalah salah satu keuntungan belanja online karena mereka dapat menawarkan akses dengan waktu, tempat, kecepatan, dan antrian tanpa batas. Selain itu, belanja online dapat membawa transaksi cepat dan waktu belanja yang efisien (Lloyd, Chan, Yip, \& Chan, 2014). Belanja secara daring tidak hanya menawarkan penghematan waktu saja tetapi juga mengurangi stres. Ada beberapa alasan untuk menyimpulkan pentingnya menghemat waktu, seperti: menghilangkan waktu perjalanan ke toko (Rohm \& Swaminathan, 2004), kaitannya dengan manfaat dan pilihan pembelian, dan perilaku pembelian kesederhanaan (S. Y. Kim \& Lim, 2001; Morganosky \& Cude, 2000), termasuk kemampuan e-commerce untuk memberikan solusi belanja kapan saja dan di mana saja tanpa harus memikirkan antrian, tempat parkir, kemacetan lalu lintas atau terjebak dalam keramaian (Childers, Carr, Peck, \& Carson, 2001).

Berdasarkan argument dan penelitian tersebut diatas, dapat simpulkan belanja secara daring merupakan bentuk penghematan waktu belanja bagi konsumen. Oleh karena itu, situs harus mampu menyediakan kebutuhan dan keinginan konsumen yang berbeda sehingga mereka dapat berbelanja tanpa harus mendatangi toko. Semakin tinggi tingkat penghematan waktu saat berbelanja daring, semakin tinggi tingkat kepuasan konsumen. Hipotesis ketiga yang diajukan:

\section{H3: Penghematan waktu mempengaruhi kepuasan}

Pengalaman positif yang diterima konsumen pada saat berbelanja daring merupakan hasil perbandingan dengan belanja secara konvensional. Estimasi waktu yang dibutuhkan sejak produk di pesan hingga produk dan layanan dapat dinikmati menjadi titik tolak perbandingan. Efisiensi waktu belanja hingga produk sampai ditangan konsumen merupakan hasil dari estimasi tersebut. Jika konsumen memilih metode belanja secara daring menunjukkan kepuasan atas keputusan mereka. Apabila ada seseorang yang meminta referensi belanja, maka dengan pembeli daring akan memberikan pendekatan dan stimulan untuk memilih belanja daring. Dengan demikian, hipotesis keempat yang diajukan:

H4: Waktu yang disimpan secara positif memengaruhi word of mouth.

Pelanggan bermaksud mengunjungi situs dengan varian produk yang tinggi untuk memenuhhi kebutuhan dan keinginan yang berbeda. Semakin tinggi varian produk, semakin tinggi niat mereka untuk mengunjungi situs. Berbeda dengan toko konvensional yang menghadapi masalah keterbatasan ruang, toko online memiliki kesempatan dalam menawarkan sejumlah besar varian dan kategori produk. Singkatnya, toko online dapat melayani berbagai pelanggan berdasarkan kebutuhan, keinginan, dan selera mereka. Beberapa penelitian sebelumnya membuktikan bahwa variasi produk yang ditawarkan oleh suatu situs web dapat mempengaruhi kepuasan pelanggan (Guo et al., 2012; Lin et al., 2011). Mereka berdua setuju bahwa semakin banyak variasi produk yang ditawarkan 
oleh perusahaan, semakin tinggi kemungkinan pelanggan akan puas. Dengan demikian, Hipotesis kelima yang diajukan:

\section{H5: Varietas Produk berpengaruh positif terhadap kepuasan.}

Variasi produk merupakan salah satu keunggulan pasar online karena mereka tidak memiliki ruang besar untuk menyimpan produk-produk tersebut. Di pasar online, calon pembeli dapat melihat banyak pilihan kategori produk dan varian produk. Saat calon pelanggan mencari saran, pelanggan yang berpengalaman bisa bersaksi tentang opsi produk yang ditawarkan situs. Hipotesis keenam yang diajukan:

H6: Varietas Produk secara positif mempengaruhi word of mouth.

Dalam konteks e-commerce, kinerja pengiriman adalah masalah penting bagi pelanggan. Mereka mengharapkan pengiriman yang andal, aman, dan tepat waktu sebagai jaminan pembelian. Andal mengacu pada pengiriman produk yang tepat ke tujuan secara akurat. Aman mengacu pada sejauh mana kemasan dapat menampung bahkan produk yang rapuh. Tepat waktu merujuk pada bagaimana paket tiba karena janji penyedia. Kegagalan kinerja pengiriman akan mengubah harapan pelanggan menjadi persepsi negatif. Begitu mereka memiliki pengalaman negatif tentang masalah tersebut, ketidakpuasan mereka akan menyebabkan beralihnya perilaku dengan mudah dari satu web ke web lain.

Pengaruh kinerja pengiriman pada kepuasan pelanggan telah dipelajari oleh (Guo et al., 2012) dan (Lin et al., 2011). Mereka berpendapat bahwa kinerja pengiriman yang tinggi akan meningkatkan kepuasan pelanggan. Dengan demikian hipotesis ketujuh yang diajukan:

H7: Kinerja pengiriman secara positif mempengaruhi kepuasan

Kinerja pengiriman sangat penting bagi pelanggan berkenaan dengan kekhawatiran mereka tentang kecepatan pengiriman paket dan apakah produk tiba dengan aman dan tepat. Pelanggan berpengalaman yang terlibat dalam pembelian online dapat menjadi informan utama bagi calon pembeli dalam menggambarkan bagaimana penyedia mengelola transshipment mereka. Pelanggan potensial dapat diyakinkan oleh pengalaman pelanggan untuk membeli melalui pasar online. Hipotesis kedelapan yang diajukan:

H8: Kinerja pengiriman secara positif mempengaruhi word of mouth.

Word of mouth telah memainkan peran penting dalam pemasaran jasa sejak diidentifikasi oleh Mangold, Miller, \& Brockway, (1999) dalam penelitiannya. Selanjutnya, konstruk ini kemudian menjadi fenomena sejak pertumbuhan perdagangan elektronik semakin mengglobal (Liu, Sudharshan, \& Hamer, 2000). Dalam penelitian mereka, word of mouth adalah konsekuensi dari kepuasan pelanggan dalam konteks komunikasi pribadi. Pelanggan akan termotivasi untuk mendorong teman dan kerabat mereka jika mereka menikmati dan memiliki pengalaman positif. Hipotesis kesembilan yang diajukan:

H9: Kepuasan Pelanggan secara positif mempengaruhi word of mouth.

\section{METODE}

Penelitian ini dilakukan dengan pendekatan eksplanatori dan menggunakan sampel non probabilitas dengan metode purposive sampling untuk mendapatkan data primer. Sampel yang memenuhi syarat adalah partisipan yang melakukan pembelian online lebih dari satu 
kali. Hal ini dikarenakan adanya variable kepuasan konsumen yang dikarakteristikan hanya terjadi jika partisipan melakukan pembelian ulang.

Total 20 item parameter kuesioner yang digunakan dalam investigasi ini mewakili enam variabel. Parameter desain situs, variasi produk, dan kinerja pengiriman diadopsi dari (Guo et al., 2012), sementara parameter penghematan waktu diadaptasi dari (Devaraj et al., 2002). Untuk mengukur kepuasan konsumen dan parameter word of mouth diambil dari (Bearden, Netemeyer, \& Haws, 1993). Selanjutnya, kuesioner penelitian ini menggunakan 7-pont Likert-like scale dan disusun secara tertutup. Kuesioner dibagi dalam 2 (dua) bagian, yaitu demografi responden dan parameter pengukuran. Pengumpulan data diperiksa dan ditinjau dengan seksama untuk memastikan bahwa semua kuesioner diisi dengan baik dan benar oleh responden. Setelah menyelesaikan proses pengecekan kuesioner, data kemudian akan dianalisis menggunakan metode PLS-SEM untuk mengetahui hubungan antar variabel.

\section{HASIL DAN PEMBAHASAN}

Dari 120 kuesioner yang didistribusikan, total 100 diantaranya dapat digunakan, dan oleh karena itu dinyatakan memenuhi syarat untuk digunakan lebih lanjut dalam penelitian ini. Sebelum melakukan analisis pada data, analisis demografi responden dilakukan untuk mengetahui profil responden. Berdasarkan hasil, terungkap bahwa perempuan adalah mayoritas responden (67\%) daripada laki-laki (33\%). Sementara itu, rentang usia bervariasi dalam tiga klasifikasi. Di bawah 20 tahun tercatat hanya 1\%, sedangkan responden berusia antara 21 hingga 23 tahun dominan sebanyak 97\%, dan sisanya di atas 23 tahun hanya $2 \%$.

Table 1. Demografi Respondent

\begin{tabular}{cccc}
\hline Variabel Demografi & Category & Frekuensi & Persentase \\
\hline Gender & Pria & 33 & $33 \%$ \\
& Wanita & 67 & $67 \%$ \\
& $<20$ & 1 & $1 \%$ \\
Situs Belanja & $21-23$ & 97 & $97 \%$ \\
& $>23$ & 2 & $2 \%$ \\
& Tokopedia & 43 & $43 \%$ \\
& Shoppe & 30 & $30 \%$ \\
& Lazada & 16 & $16 \%$ \\
& Bukalapak & 8 & $8 \%$ \\
\hline
\end{tabular}

Selain itu, tokopedia dan shoppe adalah pasar daring yang paling banyak menjadi tempat pembelian daring (masing-masing 43\% dan 30\%). Kedua marketplace diikuti oleh Lazada dan Bukalapak (masing-masing 16\% dan 8\%). Posisi terakhir ditempati oleh blibli. com sebessar 3\%. Meskipun online marketplace di Indonesia masih tersedia yang lain seperti Bhineka.com, Matahari Mall, ataupun Zalora, namun tidak teridentifikasi dalam penelitian ini. Sementara itu, penelitian ini tidak mmenyertakan online marketplace seperti Traveloka, Tiket.com, Oyo, dan Reddoorz karena tidak mewakili variasi produk dan layanan yang tinggi. Selanjutnya, kami menganalisis hubungan antar variable. 
Table 2. Measurement Model (Outer Model) Assessment

\begin{tabular}{|c|c|c|c|c|}
\hline Items & Variables & Cronbach's alpha & $\begin{array}{l}\text { Composite } \\
\text { Reliability }\end{array}$ & AVE \\
\hline WD1 & \multirow{3}{*}{ Desain Situs } & \multirow{3}{*}{0.771} & \multirow{3}{*}{0.865} & \multirow{3}{*}{0.683} \\
\hline WD2 & & & & \\
\hline WD3 & & & & \\
\hline TS1 & \multirow{3}{*}{ Penghematan Waktu } & \multirow{3}{*}{0.705} & \multirow{3}{*}{0.83} & \multirow{3}{*}{0.623} \\
\hline TS2 & & & & \\
\hline TS3 & & & & \\
\hline PV1 & \multirow{3}{*}{ Variasi Produk } & \multirow{3}{*}{0.802} & \multirow{3}{*}{0.882} & \multirow{3}{*}{0.714} \\
\hline PV2 & & & & \\
\hline PV3 & & & & \\
\hline DP1 & \multirow{3}{*}{ Kinerja Pengiriman } & \multirow{3}{*}{0.629} & \multirow{3}{*}{0.803} & \multirow{3}{*}{0.579} \\
\hline DP2 & & & & \\
\hline DP3 & & & & \\
\hline CS1 & \multirow{3}{*}{ Kepuasan Konsumen } & \multirow{3}{*}{0.885} & \multirow{3}{*}{0.92} & \multirow{3}{*}{0.742} \\
\hline CS2 & & & & \\
\hline cs3 & & & & \\
\hline WoM1 & \multirow{4}{*}{ Word of Mouth } & \multirow{4}{*}{0.809} & \multirow{4}{*}{0.881} & \multirow{4}{*}{0.649} \\
\hline WoM2 & & & & \\
\hline WoM3 & & & & \\
\hline WoM4 & & & & \\
\hline
\end{tabular}

Sebelum data dianalisis untuk mengukur sejauhmana anteseden memiliki efek kausal pada kepuasan pelanggan dan dari mulut ke mulut, kita perlu mengklarifikasi validitas dan reliabilitasnya. Oleh karena itu, kita perlu memastikan apakah data dan model sesuai dengan beberapa kriteria, seperti nilai factor loading dari setiap item harus melebihi 0,7, nilai AVE harus melebihi 0,5, dan nilai akar kuadrat dari AVE harus lebih besar daripada korelasi antara variabel laten melalui penilaian validitas diskriminan. Selanjutnya, Alpha Cronbach harus lebih dari 0,6 sedangkan composite reliability setidaknya 0,7.

Tabel 2 menunjukkan semua kriteria Cronbach Alpha dan variabel komposit melebihi kriteria. Dengan demikian, semua parameter item dapat diandalkan. Sementara itu, skor AVE untuk semua item melebihi 0,5 . Artinya, semua item variabel valid.

Table 3. Discriminant Validity Assessment

\begin{tabular}{|c|c|c|c|c|c|c|}
\hline & $\begin{array}{l}\text { Kepuasan } \\
\text { Konsumen }\end{array}$ & $\begin{array}{c}\text { Kinerja } \\
\text { Pengiriman }\end{array}$ & $\begin{array}{c}\text { Penghematan } \\
\text { Waktu }\end{array}$ & $\begin{array}{l}\text { Variasi } \\
\text { Produk }\end{array}$ & $\begin{array}{l}\text { Word of } \\
\text { Mouth }\end{array}$ & $\begin{array}{c}\text { Desain } \\
\text { Situs }\end{array}$ \\
\hline \multicolumn{7}{|l|}{$\begin{array}{l}\text { Kepuasan } \\
\text { Konsumen }\end{array}$} \\
\hline Kinerja Pengiriman & 0.796 & & & & & \\
\hline Penghematan Waktu & 0.575 & 0.951 & & & & \\
\hline Variasi Produk & 0.581 & 0.963 & 0.53 & & & \\
\hline Word of Mouth & 0.77 & 0.924 & 0.762 & 0.737 & & \\
\hline Desain Situs & 0.557 & 0.807 & 0.559 & 0.448 & 0.732 & \\
\hline
\end{tabular}


Kami menganalisis hubungan antara variabel untuk menentukan apakah anteseden memiliki konsekuensi pada orang lain. Ada dua persyaratan untuk memastikan efek kausal. Pertama, nilai R-squared (R2) setinggi mungkin. Kedua, nilai koefisien jalur harus lebih dari nilai cut-off 1,96 dengan tingkat signifikan 5\%. Jika hubungan kedua konstruk lebih dari 1,96 dapat disimpulkan bahwa hipotesis didukung.

Table 4. R-Squared Assessment

\begin{tabular}{cc}
\hline Variable & R-Squared \\
\hline Kepuasan Konsumen & 0.435 \\
Word of mouth & 0.638 \\
\hline
\end{tabular}

Tabel 4 mengungkapkan bahwa nilai r-square adalah 0,435 atau 43,5\%. Ini berarti kepuasan pelanggan dapat dijelaskan oleh desain situs, penghematan waktu, variasi produk, dan kinerja pengiriman sebesar 43,5\%, sedangkan sisanya 56,5\% dikontribusikan oleh pihak lain yang tidak termasuk dalam penyelidikan. Sementara itu, Word of mouth juga dapat dijelaskan oleh desain situs, penghematan waktu, variasi produk, kinerja pengiriman, dan kepuasan pelanggan sebanyak 0,638 atau 63,8\% sedangkan sisanya 36,2\% dikontribusikan oleh variabel lain yang tidak termasuk dalam penelitian ini.

Table 5. Path Coefficient analysis

\begin{tabular}{|c|c|c|c|}
\hline Relationship between Variables & t-statistic & P-Value & $\begin{array}{c}\text { Hypotheses Testing } \\
\text { Result }\end{array}$ \\
\hline Desain Situs - Kepuasan Konsumen & 2.105 & 0 & Signifikan \\
\hline Penghematan Waktu - Kepuasan Konsumen & 1.96 & 0.05 & Signifikan \\
\hline Variasi Produk - Kepuasan Konsumen & 1.235 & 0.21 & n.s \\
\hline Kinerja Pengiriman - Kepuasan Konsumen & 2.126 & 0.03 & Signifikan \\
\hline Desain Situs - word of mouth & 3.012 & 0 & Signifikan \\
\hline Penghematan Waktu - word of mouth & 2.418 & 0.01 & Signifikan \\
\hline Variasi Produk - word of mouth & 2.783 & 0 & Signifikan \\
\hline Kinerja Pengiriman - word of mouth & 0.709 & 0.47 & n.s \\
\hline Kepuasan Konsumen - word of mouth & 3.781 & 0 & Signifikan \\
\hline
\end{tabular}

Tabel 5 menunjukkan koefisien korelasi antar variabel untuk menggambarkan pengujian hipotesis dalam penelitian ini. Pengujian hipotesis dimulai dengan estimasi hubungan antara desain situs dengan kepuasan pelanggan dan word of mouth. Hasil penelitian menunjukkan bahwa desain situs web secara signifikan mempengaruhi kepuasan pelanggan (2.105) dan word of mouth (3.012). Oleh karena itu, hipotesis 1 dan 2 diterima.

Temuan berikutnya menyatakan bahwa penghematan waktu secara positif mempengaruhi kepuasan pelanggan dan word of mouth. Hasil penelitian menunjukkan bahwa penghematan waktu secara signifikan mempengaruhi kepuasan pelanggan (1.960) dan word of mouth (2.418). Oleh karena itu, hipotesis 3 dan 4 diterima.

Hasil pengujian menunjukkan bahwa variasi produk secara positif mempengaruhi kepuasan pelanggan dan word of mouth. Hasil penelitian menunjukkan bahwa variasi 
produk tidak mempengaruhi kepuasan pelanggan secara signifikan (1.235). Namun, gagasan hubungan antara variasi produk dan word of mouth menunjukkan yang signifikan $(2,783)$. Oleh karena itu, hipotesis 5 ditolak sementara 6 diterima

Selanjutnya ditemukan kinerja pengiriman secara positif mempengaruhi kepuasan pelanggan dan dari word of mouth. Hasil penelitian menunjukkan bahwa kinerja pengiriman berpengaruh signifikan terhadap kepuasan pelanggan $(2,126)$. Namun demikian, hubungan antara kinerja pengiriman dan word of mouth menunjukkan hasil yang berlawanan $(0,709)$. Oleh karena itu, hipotesis 7 diterima sedangkan 8 ditolak.

Terakhir, hasil temuan menunjukkan bahwa kepuasan pelanggan secara positif mempengaruhi word of mouth. Hasil penelitian menunjukkan bahwa kepuasan pelanggan mempengaruhi word of mouth secara signifikan $(3,781)$. Oleh karena itu, hipotesis 5 diterima.

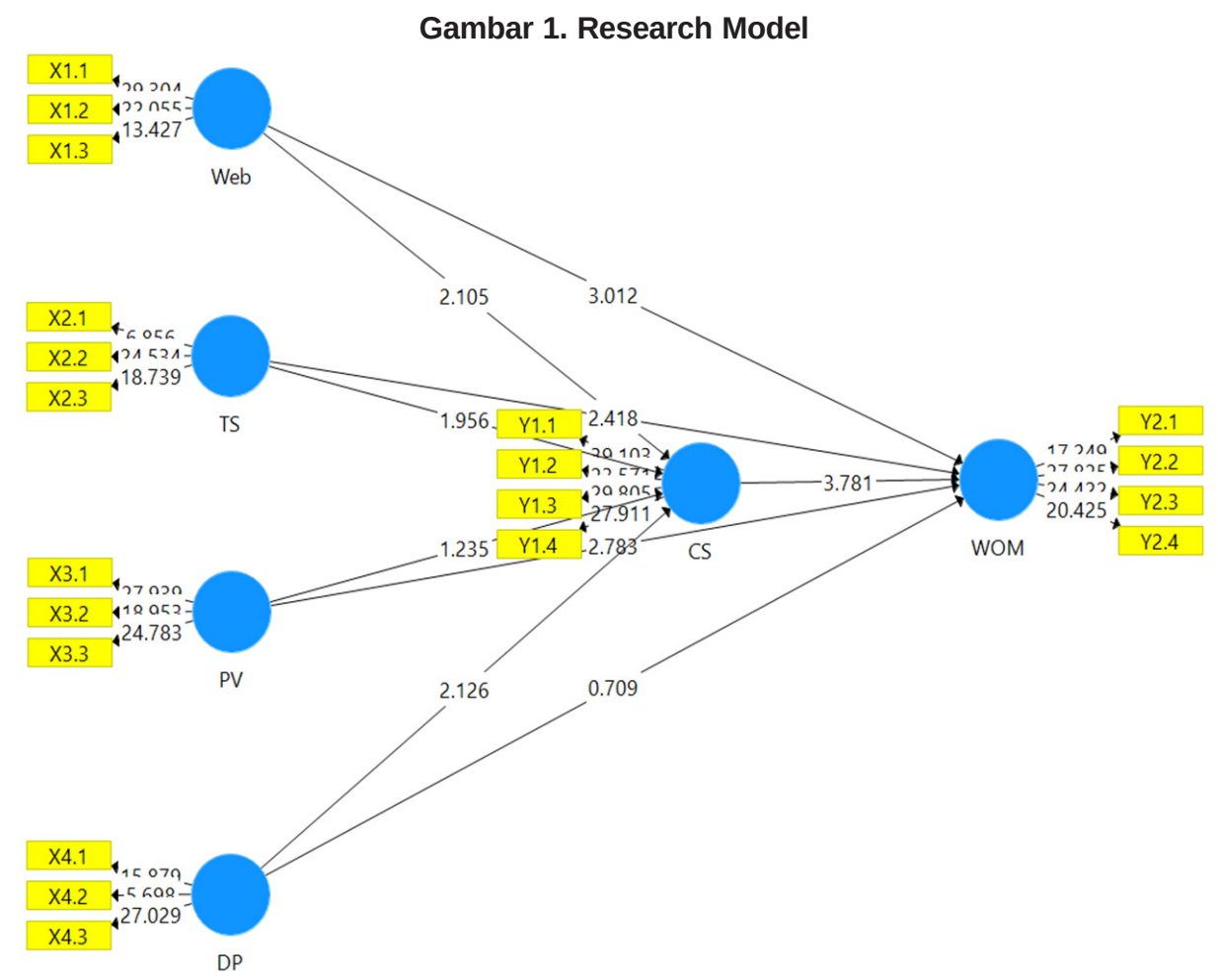

Pengujian hipotesis mengungkapkan berbagai hasil antara variabel independen dan hubungan variabel dependen. Pada hipotesis pertama, desain situs secara signifikan mempengaruhi kepuasan pelanggan dan dari word of mouth. Seperti yang kami katakan sebelumnya, desain situs yang baik terdiri dari tampilan visual yang menarik, navigasi sederhana, dan mudah digunakan. Sementara itu, penelitian lain berpendapat bahwa situs yang layak terdiri dari kustomisasi, informatif, aman dan privasi, konsistensi, dan kemudahan memahami dan memesan (Tandon et al., 2017). Ketika pengunjung melihat elemen-elemen itu melekat pada situs web, kemungkinan kepuasan akan meningkat. Hasilnya mendukung untuk penelitian sebelumnya (Guo et al., 2012; Wolfinbarger \& Gilly, 2003) yang menemukan hasil yang identik. Sementara itu, pada hipotesis kedua, pelanggan yang memiliki pengalaman positif dengan desain situs akan berkomunikasi dengan relasi mereka tentang situs yang ada. 
Mereka akan memberikan testimonial positif mengenai elemen-elemen itu sebagai bahan referensi bagi rekan kerja, keluarga, atau teman mereka. Chung \& Shin, (2009) menemukan efek tidak langsung dari situs pada word of mouth. Mereka menyatakan bahwa karakteristik situs dapat mengarahkan pengunjung untuk memberi tahu pelanggan mengenai produk dan layanan.

Pada hipotesis ketiga, penghematan waktu mempengaruhi kepuasan pelanggan word of mouth secara signifikan. Pengunjung yang melakukan pembelian melalui online adalah pembeli yang mempertimbangkan keterbatas waktu, menghindari biaya dan waktu perjalanan, dan melarikan diri dari keramaian dalam toko. Pembelian online adalah satusatunya cara untuk menghemat waktu mereka. E-commerce ditawarkan cara mudah untuk membeli dengan kemungkinan kehilangan waktu yang lebih sedikit. Pelanggan akan puas jika mereka terlibat dalam menghemat waktu dalam pembelian online daripada membuang-buang waktu mereka mengunjungi toko secara fisik. Hasil ini sejalan dengan penelitian sebelumnya (Rudansky-Kloppers, 2014). Selanjutnya, hipotesis keempat, penjelasan penghematan waktu dan hubungan word of mouth terjadi dari pengalaman masa lalu. Ketika pelanggan menjelajahi situs, dianalogikan sama dengan mengunjungi toko. Meskipun demikian, tindakan ini dapat dilakukan dengan duduk di rumah dan melakukannya dengan satu klik. Bukan saja menghemat waktu mereka, tetapi juga energi mereka. Kesenangan dan kesederhanaan akan menjadi poin yang baik untuk berbagi pengalaman kepada orang lain.

Pada hipotesis kelima, hubungan variasi produk dengan kepuasan pelanggan tidak signifikan. Meskipun penyelidikan sebelumnya menunjukkan bahwa hubungan antara variasi produk dan kepuasan pelanggan adalah signifikan (Guo et al., 2012), tetapi dalam penelitian ini tidak ditemukan keberadaannya. Hal ini disebabkan pelanggan yang melakukan pembelian online bukan pembeli impulsif melainkan pembeli rasional. Mereka bermaksud berselancar di situs untuk melakukan pembelian sesuai tujuan mereka. Karena itu, niat mereka dalam pembelian online adalah untuk membeli secara khusus. Namun, pada pengujian hipotesis keenam, kami menemukan bahwa variasi produk dapat mendukung perilaku word of mouth secara signifikan. Hasilnya didukung untuk penyelidikan sebelumnya (Rudansky-Kloppers, 2014). Situs-situs yang menawarkan berbagai macam produk dan menambahkan beberapa informasi yang cukup seperti jenis produk, deskripsi, instruksi, ulasan produk, atau bahkan demonstrasi akan memastikan peningkatan kemungkinan referensi word of mouth.

Pada hipotesis ketujuh, kami menemukan bahwa kinerja pengiriman secara signifikan mempengaruhi kepuasan pelanggan. Ini juga mendukung eksplorasi sebelumnya oleh (Lin et al., 2011) yang menemukan bahwa kinerja pengiriman terdiri dari waktu, reliabilitas, dan akses yang tepat adalah penentu yang tepat untuk meningkatkan kepuasan pelanggan. Namun, hubungan antara kinerja pengiriman dan word of mouth tidak signifikan. Ini mungkin terjadi karena situs tidak bertanggung jawab dalam aktivitas pengiriman. Di Indonesia, proses pengiriman ke pihak ketiga adalah hal yang biasa. Pasar online berkolaborasi dengan beberapa perusahaan kurir untuk mendistribusikan pesanan pelanggan. Pelanggan dapat memilih kurir mana yang mereka inginkan dan berapa lama pesanan akan tiba. Akibatnya, biaya transshipment mengikuti pilihan mereka. Itu sebabnya pelanggan tidak akan melihat kinerja pengiriman sebagai kunci utama, karena itu bukan tanggung jawab toko daring. 
Hipotesis kedelapan, hasil pengukuran membuktikan adanya pengaruh kepuasan pelanggan terhadap word of mouth. Itu berarti ketika pelanggan puas dengan pengalaman mereka saat berselancar atau membeli di situs, mereka akan menceritakan situs untuk rekan, kerabat, atau keluarga mereka dengan sukarela. Hasil ini juga mendukung studi sebelumnya (Babin et al., 2005; Lloyd et al., 2014).

Kejutan dalam penelitian ini adalah ditemukannya peran kepuasan pelanggan sebagai variabel mediasi. Dalam penelitian ini, kepuasan pelanggan berperan sebagai mediasi baik dari desain situs maupun penghematan waktu menuju word of mouth. Sementara yang lain gagal karena tidak memenuhi persyaratan. Sebagai variabel mediasi parsial, kepuasan pelanggan dapat meningkatkan kemungkinan dari mulut ke mulut. Hasil ini sekaligus mengkonfirmasi studi sebelumnya ketika kepuasan pelanggan menjadi mediasi dari kongruensi diri kepada niat untuk beli (Ekinci et al., 2008), dan dari kualitas situs kepada niat pembelian kembali (Tandon et al., 2017)

\section{SIMPULAN}

Pengujian hipotesis mengungkapkan bahwa desain situs, penghematan waktu, dan kinerja pengiriman memiliki efek positif pada kepuasan pelanggan. Sebaliknya, variasi produk menunjukkan sebaliknya. Sementara itu, desain situs, penghematan waktu, variasi produk, dan kepuasan pelanggan memiliki efek positif kepada word of mouth. Meskipun demikian, hubungan kinerja pengiriman dengan word of mouth tidak signifikan. Selain itu, kami juga menemukan bahwa kepuasan pelanggan memainkan peran besar sebagai variabel intervening dari desain situs dan penghematan waktu menuju word of mouth.

Secara praktik, ketika perusahaan memilih untuk beroperasi di e-commerce, mereka perlu memperhatikan anteseden yang mendorong kepuasan pelanggan. Pelanggan yang memiliki pengalaman positif pada desain situs, penghematan waktu, dan kinerja pengiriman akan meningkatkan kepuasan. Selain itu, elemen-elemen tersebut juga berkontribusi dalam mendorong word of mouth.

Terlepas dari semua hasilnya, penelitian ini tidak lepas dari sejumlah keterbatasan. Pertama, investigasi dilakukan di 1 (satu) kota saja. Dengan demikian, generalisasi hasil tidak mungkin direkomendasikan. Oleh karena itu, kami menyarankan penelitian lebih lanjut berdasarkan latar belakang lintas budaya untuk memahami perilaku konsumen. Kedua, kami menyarankan beberapa anteseden seperti privasi dan keamanan, keandalan, risiko yang dipersepsikan, atau ketersediaan informasi untuk melengkapi studi ini. Ketiga, kami melakukan sampel spesifik yaitu usia remaja. Kami menganggap usia 20-25 tahun adalah rentang usia yang terbiasa dengan aktivitas e-commerce. Keempat, word of mouth adalah satu-satunya konsekuensi dalam penelitian ini. Bagaimanapun, kami menyarankan lebih banyak variable konsekuensi karena kepuasan dapat mempengaruhi beberapa variabel seperti perilaku pembelian berulang atau loyalitas.

Berdasarkan temuan, perusahaan perlu mempertimbangkan beberapa anteseden kepuasan pelanggan, yaitu: desain situs web, penghematan waktu, dan kinerja pengiriman. Oleh karena itu, perusahaan harus membangun situs terbaik dengan tampilan visual yang lebih baik, sederhana dan informatif, serta mudah dipahami dan dinavigasi. Selanjutnya, 
perusahaan harus memastikan bahwa mereka dapat menawarkan penghematan waktu bagi pelanggan. Kemudian, mereka perlu menjamin tentang proses pengemasan dan pengiriman, termasuk produk yang tepat, tujuan, dan waktu yang tepat sesuai dengan janji.

Untuk mencapai keuntungan lain bagi perusahaan melalui word of mouth, desain situs, penghematan waktu, variasi produk, dan kepuasan pelanggan sangat dianjurkan untuk dilakukan. Perusahaan perlu menyediakan situs yang unggul dan untuk memastikan pembelian online lebih baik daripada harus membeli di toko. Lebih jauh, semakin luas variasi produk dan kategori produk yang mereka tawarkan, semakin tinggi kemungkinan pelanggan akan merekomendasikan kepada rekan dan kerabat mereka. Kemungkinan karena situs dapat menyimpan lebih banyak dari dari toko konvensional. Selain itu, pelanggan yang puas tentang situs dan memiliki pengalaman positif dalam menghemat waktu akan mendukung rekan dan kerabat mereka.

Karena kami menggunakan 4 (empat) penentu desain situs dalam penyelidikan ini, kami menyarankan untuk menambahkan beberapa elemen untuk dipahami dalam pemeriksaan, yaitu, keandalan, kecepatan dan informatif, konten hiburan, keamanan dan privasi, dan risiko yang dipersepsikan. Di sisi lain, kami juga mengusulkan kemungkinan hadirnya efek moderasi demografi responden pada niat perilaku pelanggan selanjutnya. Kami juga menyarankan untuk memeriksa dalam paradigma lintas budaya antara penduduk kota dan pinggiran kota mengenai keputusan pembelian online.

\section{PUSTAKA ACUAN}

Babin, B. J., Lee, Y., Kim, E., \& Griffin, M. (2005). Modeling consumer satisfaction and wordof-mouth : restaurant patronage in Korea. Journal of Services Marketing, 19(3), 133-139. https://doi.org/10.1108/08876040510596803

Bearden, W. O., Netemeyer, R. G., \& Haws, K. L. (1993). Handbook of marketing scales (3rd ed.). Los Angeles: Sage.

Bickart, B., \& Schindler, R. M. (2001). Internet forums as influential sources of consumer information. Journal of Interactive Marketing, 15(3), 31-40. https://doi.org/10.1002/ DIR.1014

Brakus, J. J., Schmitt, B. H., \& Zarantonello, L. (2009). Brand experience: what is it? How is it measured? Does it affect loyalty? Journal of Marketing, 73(May), 52-68. https:// doi.org/10.1509/jmkg.73.3.52

Bressolles, G., \& Durrieu, F. (2011). Service quality, customer value and satisfaction relationship revisited for online wine websites. In 6th AWBR International Conference. Bordeaux.

Childers, T. L., Carr, C. L., Peck, J., \& Carson, S. (2001). Hedonic and utilitarian motivations for online retail shopping behavior. Journal of Retailing, 77(4), 511-535. https://doi. org/10.1016/S0022-4359(01)00056-2

Chung, K. H., \& Shin, J. I. (2009). The relationship between site characteristics, relationship quality, and word of mouth. International Journal of Business and Information, 4(2), 137-161.

Curry, N., \& Gao, Y. (2012). Low-cost airlines-A new customer relationship? An analysis of service quality, service satisfaction, and customer loyalty in a low-cost setting. Service Marketing Quarterly, 33, 104-118. https://doi.org/10.1080/15332969.2012.662457 
Delgado-Ballester, E., \& Munuera-Alemán, J. L. (2001). Brand trust in the context of consumer loyalty. European Journal of Marketing, 35(11), 1238-1258. https://doi.org/10.1108/ EUM0000000006475

Devaraj, S., Fan, M., \& Kohli, R. (2002). Antecedents of B2C Channel Satisfaction and Preference: Validating e-Commerce Metrics. Information Systems Research, 13(3), 316-333. https:// doi.org/10.1287/isre.13.3.316.77

Ekinci, Y., Dawes, P. L., \& Massey, G. (2008). An extended model of the antecedents and consequences of consumer satisfaction for hospitality services. European Journal of Marketing, 42(February), 35-68. https://doi.org/10.1108/03090560810840907

Elmaraghy, H. A., Elmaraghy, W. H., Scuch, G., \& Piller, F. T. (2013). CIRP annals-manufacturing technology product variety management. CIRP Annals-Manufacturing Techonology, 62(2), 1-25. https://doi.org/10.1016/j.cirp.2013.05.007

Fichter, K. (2003). E-commerce: Sorting out the environmental consequences. Journal of Industrial Ecology, 6(2), 25-41. https://doi.org/10.1162/108819802763471762

Fisher, M., Ramdas, K., \& Ulrich, K. (2014). Component sharing in the management of product variety: A study of automotive braking Systems. Management Science, 45(3), 297-315. https://doi.org/10.1287/mnsc.45.3.297

Francis, J. E. (2009). Category-specific RECIPEs for internet retailing quality. Journal of Services Marketing, 23(7), 450-461. https://doi.org/10.1108/08876040910995248

Guo, X., Ling, K. C., \& Liu, M. (2012). Evaluating factors influencing consumer satisfaction towards online shopping in China. Asian Social Science, 8(13), 40-49. https://doi. org/10.5539/ass.v8n13p40

Ha, H.-Y., \& Perks, H. (2005). Effects of consumer perceptions of brand experience on the web: brand familiarity, satisfaction and brand trust. Journal of Consumer Behaviour, 4(6), 438-452. https://doi.org/10.1002/cb.29

Kaur, G. (2011). Traditional commerce Vs E-commerce. International Research Journal of Management Science and Technology, 2(3), 334-340.

Keller, E. D., \& Fay, B. (2009). The role of advertising in word of mouth. Journal of Advertising Research, 49(2), 154-158. https://doi.org/10.2501/S0021849909090205

Kim, J., \& Lee, J. (2002). Critical design factors for successful e-commerce systems. Behaviour \& IT, 21, 185-199. https://doi.org/10.1080/0144929021000009054

Kim, S. Y., \& Lim, Y. J. (2001). Consumers' Perceived Importance of and Satisfaction with Internet Shopping. Electronic Markets, 11(3), 148-154. https://doi.org/10.1080/101967801681007988

Kotler, P., \& Armstrong, G. (2014). Principles of Marketing (15th ed.). Essex, England: Pearson.

Kotler, P., \& Keller, K. L. (2016). Marketing management. Upper Sadlle River (15th ed.). New Jersey: Pearson. https://doi.org/10.1108/ssmt.2001.21913cab.040

Lin, C. C., Wu, H. Y., \& Chang, Y. F. (2011). The critical factors impact on online customer satisfaction. Procedia Computer Science, 3, 276-281. https://doi.org/10.1016/j.procs.2010.12.047

Liu, B. S.-C., Sudharshan, D., \& Hamer, L. O. (2000). After-service response in service quality assessment: a real-time updating model approach. Journal of Services Marketing, 14(2), 160-177. https://doi.org/10.1108/08876040010321000 
Lloyd, A. E., Chan, R. Y. K., Yip, L. S. C., \& Chan, A. (2014). Time buying and time saving: Effects on service convenience and the shopping experience at the mall. Journal of Services Marketing, 28(1), 36-49. https://doi.org/10.1108/JSM-03-2012-0065

Luo, J., Ba, S., \& Zhang, H. (2012). The effectiveness of online shopping characteristics and well-designed websites on satisfaction. Management Information System Quarterly, 36(4), 1131-1144. https://doi.org/10.2307/41703501

Mangold, G. W., Miller, F., \& Brockway, G. R. (1999). Word-of-mouth communication in the service marketplace. Journal of Services Marketing, 13(1), 73-89. https://doi. org/10.1108/08876049910256186

Martin, M. V, \& Ishii, K. (2000). Design for Variety: A Methodology for Developing Product Platform Architectures. In ASME Design Engineering Technical Conferences (pp. 2-16). Baltimore.

Morgan-Thomas, A., \& Veloutsou, C. (2013). Beyond technology acceptance: Brand relationships and online brand experience. Journal of Business Research, 66(1), 21-27. https://doi. org/10.1016/j.jbusres.2011.07.019

Morganosky, M. A., \& Cude, B. J. (2000). Consumer response to online grocery shopping. International Journal of Retail \& Distribution Management, 28(1), 17-26. https://doi. org/10.1108/09590550010306737

Phelps, J. E., Lewis, R., Mobilio, L., Perry, D., \& Raman, N. (2004). Viral marketing or electronic word-of-mouth advertising: Examining consumer responses and motivations to pass along email. Journal of Advertising Research, 44(4), 333-348. https://doi.org/10.1017/ S0021849904040371

Richbell, S. (2007). Night shoppers in the "open 24 hours" supermarket: a profile. International Journal of Retail \&amp; Distribution Management, 35(1), 54-68. https:// doi.org/10.1108/09590550710722341

Rohm, A. J., \& Swaminathan, V. (2004). A typology of online shoppers based on shopping motivations. Journal of Business Research, 57(7), 748-757. https://doi.org/10.1016/ S0148-2963(02)00351-X

Rudansky-Kloppers, S. (2014). Investigating Factors Influencing Customer Online Buying Satisfaction In Gauteng, South Africa. International Business \& Economics Research Journal, 13(5), 1187. https://doi.org/10.19030/iber.v13i5.8784

Seiders, K., Voss, G. B., \& Godfrey, A. L. (2007). SERVCON: Development and validation of a multidimensional service convenience scale. Journal of the Academy of Marketing Science, 35, 144-156. https://doi.org/10.1007/s11747-006-0001-5

Shergill, G. S., \& Chen, Z. (2005). Web-based shopping consumers' attitudes toward online shopping in New Zealand. Journal of Electronic Commerce Research, 6(2), 79-94.

Strauss, J., \& Frost, R. (2014). E-Marketing (7th ed.). New York: Pearson.

Suchánek, P., \& Králová, M. (2014). Customer Satisfaction , Product Quality and. Review of Economic Perspectives, 14(4), 329-344. https://doi.org/10.1515/revecp-2015-0003

Szymanski, D. M., \& Hise, R. T. (2000). E-Satisfaction: An initial examination. Journal of Retailing, 76(3), 309-322. https://doi.org/10.1016/S0022-4359(00)00035-X 
Tandon, U., Kiran, R., \& Sah, A. N. (2017). Customer satisfaction as mediator between website service quality and repurchase intention: An emerging economy case. Service Science, 9(2), 106-120. https://doi.org/10.1287/serv.2016.0159

Tao, Z., Lu, Y., \& Wang, B. (2009). The relative importance of website design quality and service quality in determining consumers' online repurchase behavior. IS Management, 26(4), 327-337. https://doi.org/10.1080/10580530903245663

Ting, S. (2014). The relationship between customers' switching cost and repurchase intention: The moderating role of satisfaction. Journal of Service Science and Management, 7, 313-322. https://doi.org/10.4236/jssm.2014.74028

Tsai, Y.-C., Chang, H.-C., \& Ho, K.-C. (2015). A study of the relationship among brand experiences, self-concept congruence, customer satisfaction, and brand preference. Contemporary Management Research, 11(2), 97-116. https://doi.org/10.7903/cmr.12970

Turban, E., King, D., Lee, J. K., Liang, T.-P., \& Turban, D. C. (2015). Electronic Commerce: A Managerial and Social Networks Perspective (8th ed.). New York: Springer. https://doi. org/10.1007/978-3-319-10091-3

Wolfinbarger, M., \& Gilly, M. C. (2003). eTailQ: dimensionalizing, measuring and predicting etail quality. Journal of Retailing, 79, 183-198. https://doi.org/10.1016/S00224359(03)00034-4

Zwass, V. (1996). Electronic Commerce: Structures and Issues. International Journal of Electronic Commerce, 1(1), 3-23. https://doi.org/10.1080/10864415.1996.11518273 